\title{
Changes in the Loop Current's Eddy Shedding in the Period 2001-2010
}

\author{
Fred M. Vukovich \\ FMV Atmospheric and Marine Consultants, 8033 Hawkshead Rd, Wake Forest, NC 27587, USA \\ Correspondence should be addressed to Fred M. Vukovich, fmvamc@centurylink.net
}

Received 27 July 2011; Revised 22 September 2011; Accepted 21 December 2011

Academic Editor: Grant Bigg

Copyright () 2012 Fred M. Vukovich. This is an open access article distributed under the Creative Commons Attribution License, which permits unrestricted use, distribution, and reproduction in any medium, provided the original work is properly cited.

A major change in the Loop Current's eddy shedding was found in the decade 2001-2010. Sixteen (16) rings separated from the Loop Current in that decade, whereas in two previous decades, 11 rings separated in each decade. More than half the rings (i.e., $56 \%$ ) that separated from the Loop Current in the decade 2001-2010 had separation periods $\leq 8$ months. In the period prior to 2001 , only $26 \%$ of the rings had separation periods $\leq 8$ months. Furthermore, the dataset average period for ring separation for the period prior to 2001, an average over a 29-year period, was about 11 months, and the dataset average Loop Current's westward tilt angle- a factor that indicates whether the Loop Current will soon shed an eddy or not-was about $16^{\circ}$. After the year 2000, the dataset average period for ring separation, an average over a 39-year period, decreased by about 1 month and was about 10 months. The average ring-separation period in the decade 2001-2010 was about 9 months. The dataset average of the Loop Current's westward tilt angle increased by about $5^{\circ}$ in the period $1998-2008$ and was about $20^{\circ}$ in 2010 . Potential causes for these changes are discussed.

\section{Introduction}

Previous studies of the cycle of warm-core ring (WCR) separation from the Loop Current have reported average separation periods of about 11-12 months [1-6]. Studies have found that the frequency distribution is bimodal with modes at 8-9 months and 13-14 months $[7,8]$ and with modes at 6 and 11 months $[5,6]$. Vukovich $[2,4,6]$ also noted that the eddy separation periods were highly variable, ranging from 6 to 19 months. Sturges and Evans [1] have suggested that the maximum period between ring separations maybe as large as 30 months, but periods that large have not been observed as yet. The minimum eddy-shedding period previously observed was 8 months $[1,9]$. Vukovich [6], using a 32-year data set, found that the minimum eddy-shedding period was 6 months.

Vukovich [6] introduced the concept of the Loop Current orientation. The Loop Current orientation was defined as the westward tilt angle of the Loop Current. The westward tilt of the Loop Current is believed to be the result of a ring that develops within the Loop Current, but has not as yet separated from the Loop Current. The ring drifts westward, bringing the Loop Current with it, so to speak, which causes the Loop Current's westward tilt angle to increase. This processes continues until the ring separates from the Loop Current. Some of the initial westward tilting of the Loop Current may be due to the presents of the West Florida Shelf, but the larger angles are most likely due to the westward drift of the rings imbedded in the Loop Current. Using a 28-year data set (1976-2003), Vukovich [6] noted that the average westward tilt angle of the Loop Current was about $17^{\circ}$, which, it was determined from observations, indicated that the Loop Current, on average, was not about to shed a WCR anytime in the very near future. The standard deviation was about $\pm 14^{\circ}$. The mode of the dataset was $0^{\circ}$; that is, a northsouth orientation of the Loop Current was the most observed orientation. It was also determined from observations that when the Loop Current's westward tilt angle was $>30^{\circ}$, a WCR would separate from the Loop Current within about 30 to 60 days. There are cases when separation occurred in periods $>60$ days after the westward tilt angle reached $30^{\circ}$. In those cases, very large westward tilt angles were developed. A westward tilt angle of approximately $63^{\circ}$ was the maximum angle observed. Angles greater than $55^{\circ}$ were only observed 


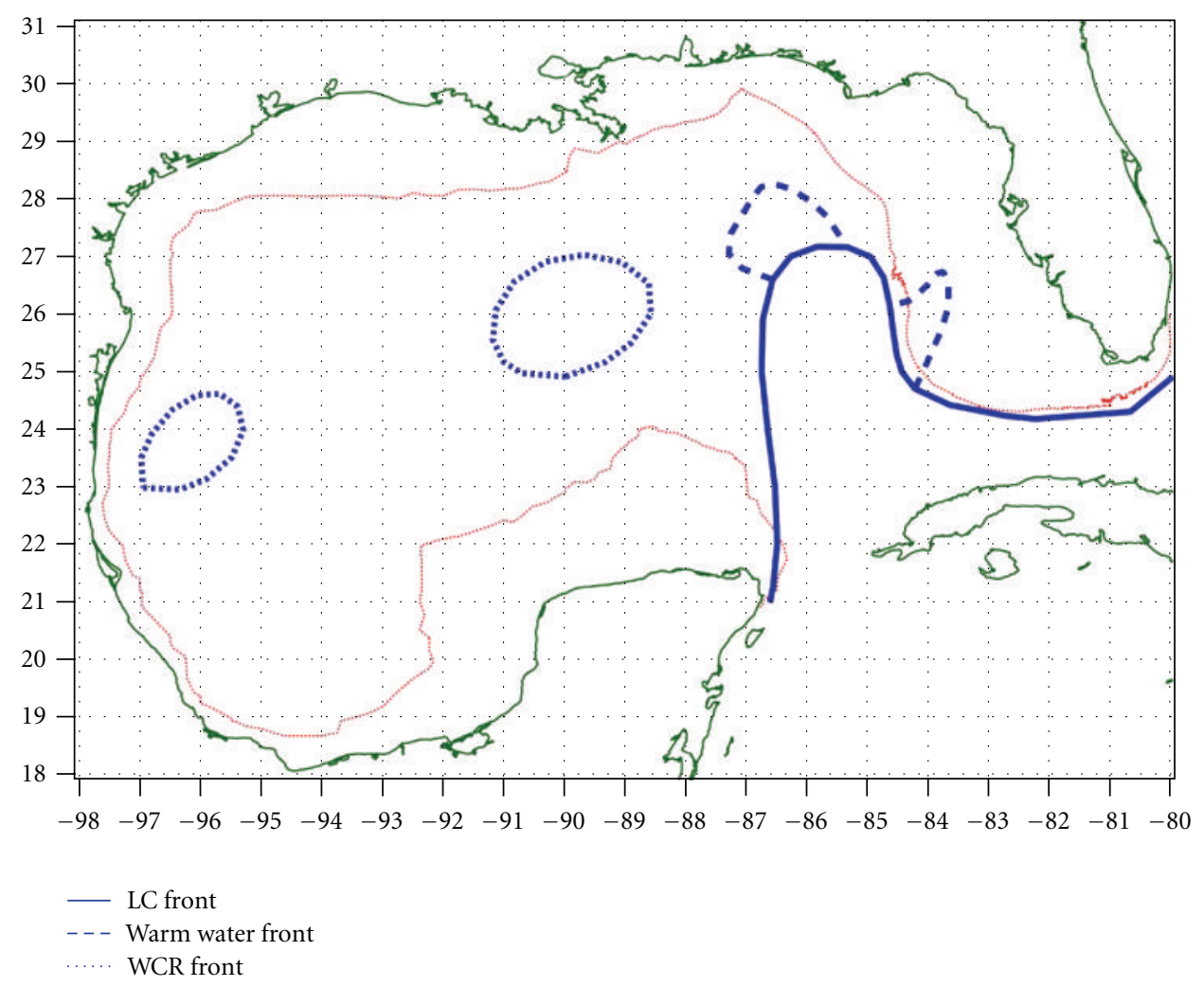

FIGURE 1: Example of the analysis of fronts in the GOM created using remote sensing data and in-situ data.

twice over the 28-year period, and angles between $50^{\circ}$ and $54^{\circ}$ were also only observed twice.

The data presented in the literature to date would suggest that over the last 30 or so years, the Loop Current eddyshedding cycle has been relatively consistent with an average period for eddy shedding of about 11-12 months and the Loop Current, on average, was not about to shed a WCR anytime soon (i.e., rings would separate with periods $\geq 8$ months). However, observations obtained in the last decade (2001-2010) indicated that changes in the Loop Current's eddy-shedding cycle have taken place. This paper presents data outlining those changes and discusses the implication of those changes relative to the forces that may affect the Loop Current's behavior.

\section{Data and Procedure}

The principal data resources used for this study included sea-surface temperature (SST) data from the Television and Infrared Observation Satellite-M (TIROS-M), the Heat Capacity Mapping Mission (HCCM) satellite, SEASAT, the Geostationary Operational Environmental Satellite (GOES), and numerous National Oceanic and Atmospheric Administration (NOAA) satellites; ocean color data from the Coastal Zone Color Scanner (CZCS), the Sea-viewing Wide field of View Sensor (SeaWiFS), and the Moderate Resolution Imaging Spectroradiometer (MODIS); altimeter data from the Ocean Topography Experiment (TOPEX/Poseidon), JASON, and the European Remote Sensing (ERS) satellite; various analyzed in-situ data from ships of opportunity and from Mineral Management Service (MMS) field programs in the Gulf of Mexico (GOM); information on the Loop Current and rings in the GOM from the programs managed by various oil and gas companies. Monthly frontal analyses were created using an integral of the available remote sensing data, any available information on ocean features, and any available analyzed in situ data for the month in question when sufficient data were available. These fronts were associated with the Loop Current, rings, and other features in the GOM, and the analyses provided "characteristic" positions of the fronts/features in the GOM for the given month. An example of a frontal analysis is presented in Figure 1. The Loop Current front in these analyses is the approximate average front for the month unless a WCR separated from the Loop Current during that month. In that case, it is the position of front after separation has occurred. These frontal analyses were used to determined eddy-shedding periods and to develop time series of the Loop Current's westward tilt angle.

Satellite remote sensing data played a major role in the development of these frontal analyses. In the periods 1972 through 1978 and 1986 through 1991, only satellite SST data were available to develop the ocean front analysis. Most of the SST data were obtained from the NOAA/AVHRR, though GOES, TIROS, and HCMM data were also applied if they were available. As a result, the frontal analyses could only be determined for about 7 months in a year, depending on when the mixed layer developed in the spring/summer and eroded in the fall. However, in the summer and in parts of the spring 
and fall when SST data were not useful, significant use was made of "ship-of-opportunity" data to fill gaps in the frontal analyses (i.e., these data were used to obtain the month in which separation of a WCR from the Loop Current occurred) when these data were available. In the period 1979 through 1985, CZCS data were used to supplement the SST data when clear-sky data could be obtained and were principally used to detect ocean features in the warm season when the mixed layer was fully developed. After 1991 when altimeter data were available, the frontal analyses could be developed for most features for all twelve months in the year, in most cases.

The eddy shedding of the Loop Current was examined using a time-series analysis of eddy-shedding periods. The eddy-separation periods were determined by documenting the month and year of the separation of each major ring for the period 1972-2010. A major ring was defined as a large ring (i.e., rings with diameters of about $300 \mathrm{~km}$ or more at the time they separated from the Loop Current), which persisted for at least five months and moved into the western GOM (WGOM). The month and year of separation was that time when the major eddy completely separated from the Loop Current. In some cases, a WCR separated from the Loop Current only to be reabsorbed by the Loop Current soon thereafter. In other cases, a WCR separated from the Loop Current twice only to be reabsorbed by the Loop Current in each case. The month and year of separation of the ring from the Loop Current for this study was defined as the month and year when complete separation occurred and the ring moved into the WGOM. Discrepancies in the time of ring separation between this study and other such studies [5] are most likely due to how complete ring separation was defined and differences in features seen in the SST, ocean color, and altimeter data. The time series of eddyshedding periods were used to create histograms of the eddyshedding periods for different time periods and to determine various statistics for the eddy-shedding periods (e.g., average, standard deviation, mode, etc.) for different time periods. Table 4 provides the data used to calculate the statistics.

Changes in the Loop Current's orientation or westward tilt angle were also examined since these changes are also associated with the process of ring separation. The Loop Current usually tilts greatest to the west at the time a WCR is about to separate. Over 30 years of observation have shown that the westward tilt angle of the Loop Current is usually $>30^{\circ}$ at the time that a ring separates (i.e., the Loop Current is oriented approximately northwest-southeast), though, as previously noted, much larger orientation angles have been observed. In some cases, elongated westward extension of the Loop Current has been observed and the high-speed currents associated with the Loop Current were observed to influence the central GOM and parts of the WGOM [6]. Observations have also shown that after the ring separates, the Loop Current usually reestablishes itself, having its northern boundary at around $25^{\circ} \mathrm{N}$, and, at that time, is usually oriented north-south (i.e., the orientation angle is $0^{\circ}$ ). As the Loop Current penetrates again into the eastern GOM (EGOM), a ring develops in the Loop Current and a westward tilt of the Loop Current begins to emerge. For this study, the Loop Current orientation was defined as the angle made by the intersection of a line drawn parallel to the eastern and western frontal boundaries of the Loop Current that is drawn through the approximate center of the Loop Current and a longitude line (Figure 2). The Loop Current's westward tilt angle was determined for each month when monthly frontal analyses were available in the period 19762010. The time series data for the westward tilt angle were used to determine various statistics (i.e., the average, the mode, the standard deviation, the maximum, and the minimum orientation angle). Table 5 provides the data used to calculate the statistics.

\section{Loop Current Eddy-Shedding Period}

A major change in the average period at which rings separated from the Loop Current occurred in the decade from 2001 through 2010. Figure 3 presents the year-to-year change in the dataset average eddy-shedding period from 1990 to 2010. The value of the average eddy-shedding period for 1990 in the figure is the 19-year average from 1972 through 1990, that for 1991 is the 20-year average from 1972 through 1991, and so on. It can be seen that the average eddy-shedding period of the Loop Current decreased in the decade 2001 through 2010 from a high value of 11.3 months in 2003 to a value of 10.1 months in 2009. Prior to 2003, there was a small-amplitude oscillation in the dataset average eddyshedding period. It varied from 11.3 months for 1994 to a low value of 10.6 months for 1996 and then went back to 11.3 months by 2003 .

The data presented in Figure 3 starts with a 19-year average for 1990 (i.e., the average from 1972 to 1990). It may have been possible to start with a 15-year data set average for 1986, which was previously reported by Vukovich [2] and which provided an average eddy-shedding period of 10.9 months, and still obtain a reasonable average value. However, averages over periods less than 15 years are extremely susceptible to the year-to-year variability of the eddy-shedding periods and become very noisy. The trends that exist in the average eddy shedding after 1990 are trends in long-term averages and were precipitated by changes, and in some cases, major changes, in eddy-shedding periods.

The histogram of the Loop Current's eddy-shedding periods for the entire period 1972 through 2010 (Figure 4) shows a bimodel distribution with a range in the periods of 4 months to 19 months. The modes are at 6 months and 11 months, and the average eddy-shedding period over the 39year period was 10.2 months and the standard deviation was about \pm 4 months (Table 1 ). Approximately $64 \%$ of the eddyshedding periods were $>8$ months with about $36 \%$ being $\leq 8$ months.

The distinction between the 29-year period before 2001 and the 10-year period after 2000 is illustrated when the data used to create Figure 4 are used to create histograms for the eddy-shedding periods that occurred before 2001 and those found after 2000. The histogram of the Loop Current's eddyshedding periods for the period from 1972 through 2000 (Figure 5) shows a single mode at 6 months and a range in the periods of 5 months to 19 months. The average eddyshedding period over the 29 -year period was 10.9 months, 


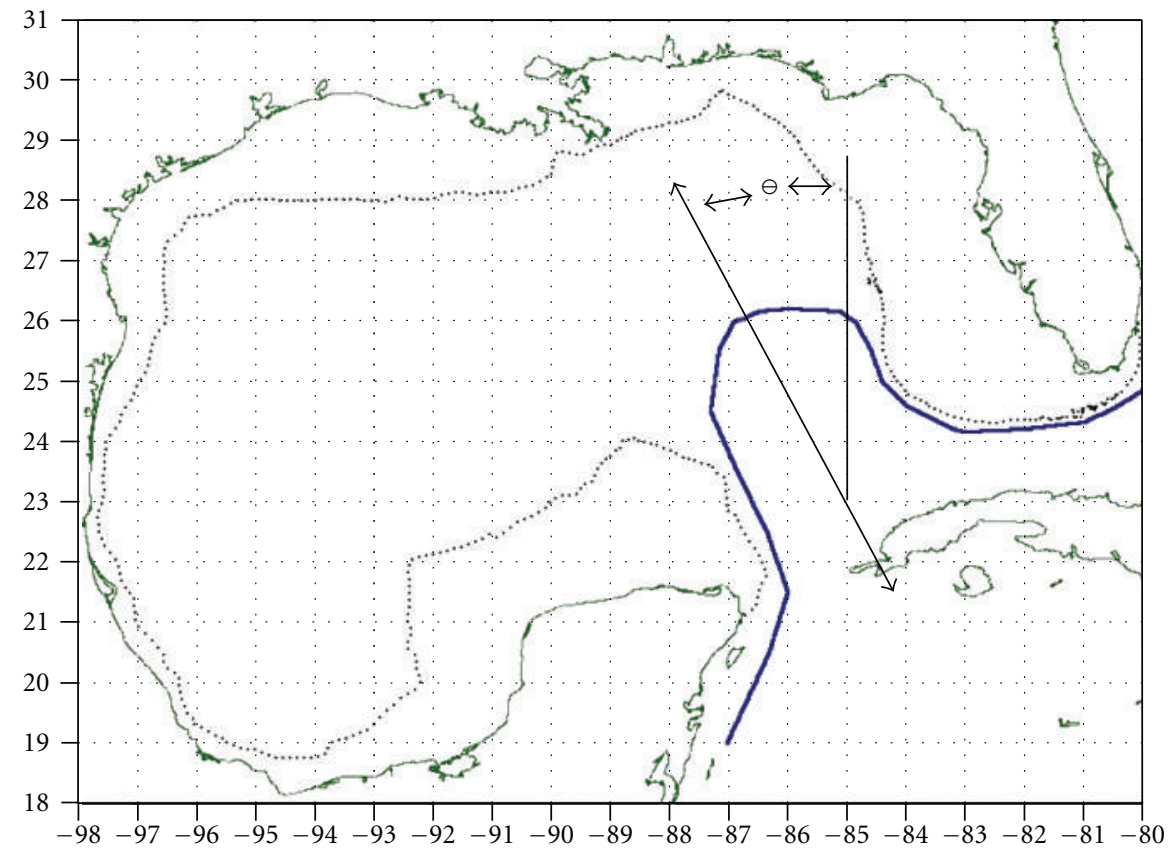

Figure 2: Procedure used determined the Loop Current's orientation angle.

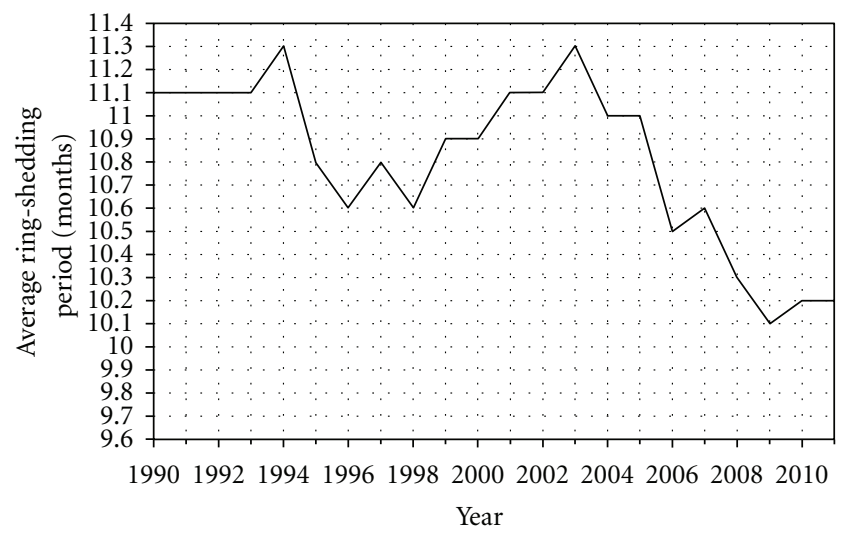

Figure 3: The average eddy-shedding period of the Loop Current for the period 1990-2010. The average value for 1990 is the 19-year average from 1972 through 1990, that for 1991 is the 20-year average from 1972 through 1991, and so on.

and the standard deviation was again about \pm 4 months (Table 1 ). Approximately $74 \%$ of the eddy-shedding periods are $>8$ months with about $26 \%$ being $\leq 8$ months.

The histogram of the Loop Current's eddy-shedding periods for the period from 2001 through 2010 (Figure 6) also shows a single mode, which is found at 4 months in this case, and the range in the periods is 4 months to 18 months. The average eddy-shedding period over the 10 -year period was approximately 8.8 months, and the standard deviation was about \pm 5 months (Table 1 ). It also should be noted that in the decades 1981-1990 and 1991-2000, the average separation periods were 11.8 and 10.5 months, respectively. Approximately $44 \%$ of the eddy-shedding periods are $>8$
TABle 1: Statistics on the Loop Current's eddy-shedding periods for various periods of time.

\begin{tabular}{lccc}
\hline Statistic & $\begin{array}{c}\text { Period of } \\
\text { data: } \\
1972-2010\end{array}$ & $\begin{array}{c}\text { Period of } \\
\text { data: } \\
1972-2000\end{array}$ & $\begin{array}{c}\text { Period of } \\
\text { data: } \\
\text { 2001-2010 }\end{array}$ \\
\hline $\begin{array}{l}\text { Average separation } \\
\text { period (month) }\end{array}$ & 10.2 & 10.9 & 8.8 \\
$\begin{array}{l}\text { Standard deviation } \\
\text { for separation period } \\
\text { (month) }\end{array}$ & \pm 4 & \pm 4 & \pm 5 \\
$\begin{array}{l}\text { Mode for separation } \\
\text { period (month) }\end{array}$ & 6 and 11 & 6 & 4 \\
$\begin{array}{l}\text { Percent of time that } \\
\text { the period } \leq 8 \text { months }\end{array}$ & $36 \%$ & $26 \%$ & $56 \%$ \\
\hline
\end{tabular}

months with about $56 \%$ being $\leq 8$ months. In previous decades (i.e., 1981-1990 and 1991-2000), the eddy-shedding periods $\leq 8$ months were $18 \%$ and $36 \%$, respectively. In the decade 2001-2010, 16 major WCRs separated from the Loop Current. In previous decades (i.e., 1981-1990 and 19912000), 11 major WCRs separated from the Loop Current in each decade, and in the 9-year period 1972-1980, 10 major WCRs separated from the Loop Current. If only one ring had separated in 1971, the decade 1971-1980 would also have had 11 major WCRs separated from the Loop Current.

The period 2001-2010 was characterized with 5 years in which more than one eddy separated in each year. In two years during that period, two rings separated from the Loop Current at the same time. The first of these events took place in 2001, and a similar event took place in 2002. Prior to ring separation, the Loop had a considerable northwest-southeast 


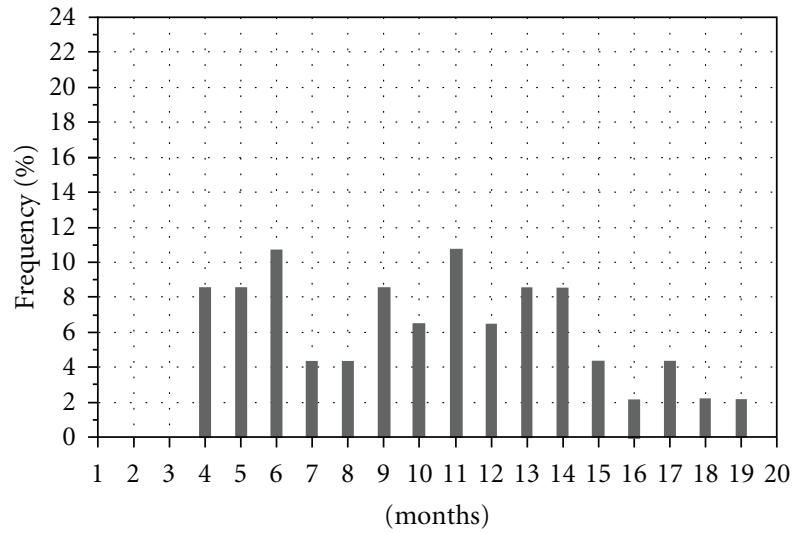

Figure 4: Histogram of the Loop Current's eddy-shedding periods for the period 1972-2010. The total number of events is 47 .

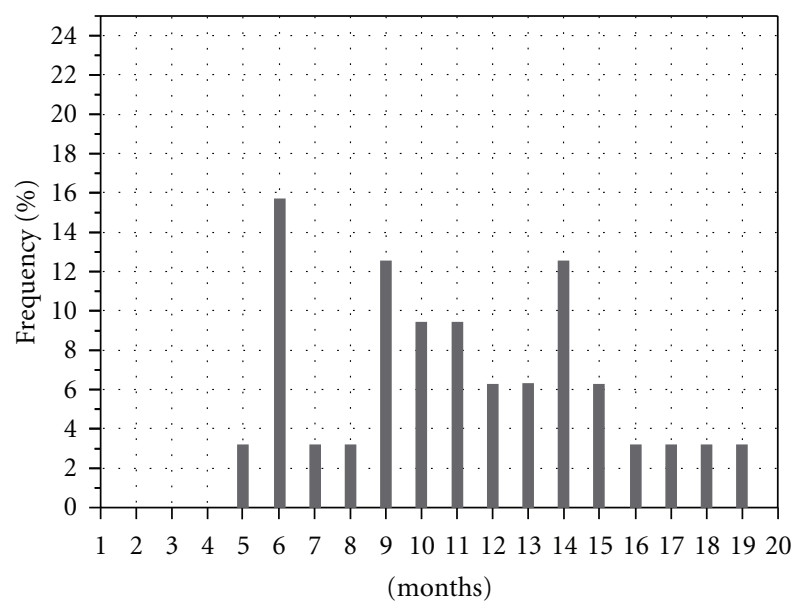

FIGURE 5: Histogram of the Loop Current's eddy-shedding periods for the period 1972-2000. The total number of events is 31 .

extension (Figures 7(a) and $8(a)$ ) in both cases. In 2002, the Loop Current was found as far west as $93^{\circ} \mathrm{W}$ and it affected the central GOM (Figure 8(a)) and parts of the WGOM as well as the EGOM. In 23 March 2001 image (Figure 7(a)), the Loop Current extended to $91^{\circ} \mathrm{W}$; however, before the rings separated in April, the Loop Current extended to $93^{\circ} \mathrm{W}$ in that case also. When the Loop Current broke down, two rings were evident in the GOM. The two rings in 2002 (Figure 8(b)) were major rings, having an initial diameter of about $300 \mathrm{~km}$. They drifted westward toward the western wall of the GOM and lasted 5 months or more before they dissipated. In 2001, two rings also separated from the Loop Current at the same time (Figure 7(b)). The ring west of the Loop Current was a major ring. The small ring near the northern boundary of the Loop Current was a minor ring. It had a diameter of about $170 \mathrm{~km}$, drifted northward into the Desoto Canyon region, and dissipated in about 3 months. An examination of our satellite remote sensing archive, which dates from 1972 to the present, indicated that no previous event similar to those in 2001 and 2002 could be found. Examination of the literature containing analyses of the Loop

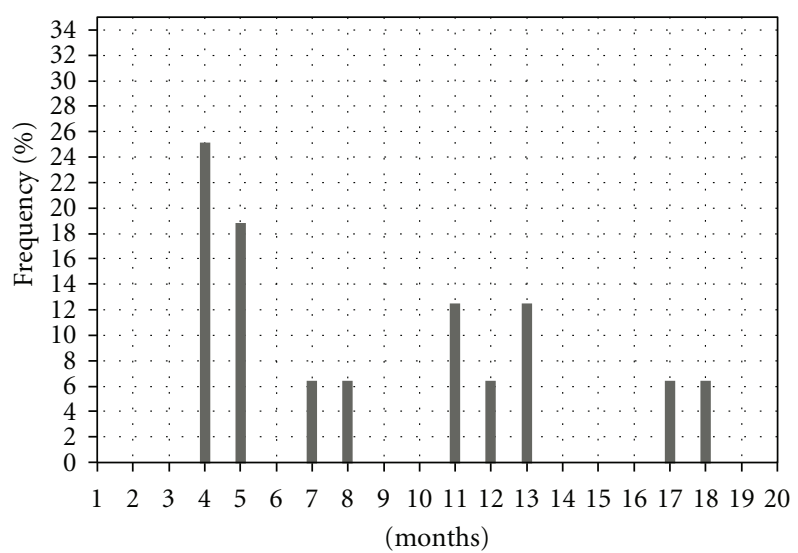

FIGURE 6: Histogram of the Loop Current's eddy-shedding periods for the period 2001-2010. The total number of events is 16 .

Current using ship survey data, which were too numerous to cite, as far back as 1932, provided no analyses of a similar event. The analyses in the literature do not possess sufficient continuity to state conclusively, however, such an event was not found in the period 1932-1972. The data prior to 1932 are very sparse.

Another interesting event occurred in 2006. In that year, three major rings separated from the Loop Current, but in this case, at different times in that year. The first major ring separated in February 2006 (Figure 9(a)) and had a separation period of 5 months (i.e., the previous ring separation occurred in 2005). The other two major rings had periods of 4 months. The first of these separated from the Loop Current in June 2006 (Figure 9(b)) and the other in October 2006 (Figure 9(c)). No similar event was found in either the archives of remote sensing imagery or in the analyses of the Loop Current using ship survey data in the literature dating back to 1932. Besides the 2006 triple separation of major rings event and the event in 2002 when two major rings simultaneously separated from the Loop Current, the period 2001-2010 was also characterized with three other years (i.e., 2004, 2008, and 2009) when two major rings separated from the Loop Current at different times during each of those years. The satellite remote sensing archive indicated there have previously been four instances when a major ring separated from the Loop Current twice during a particular year at different times. These occurred in 1975, 1986, 1995, and 1996. The consecutive years having two major rings separated from the Loop Current (i.e., in the years 1995 and 1996) were in part responsible for the oscillation in the data set average eddy-shedding period in the period 1994-2003 (Figure 3).

Though there was a major change in the number of and the statistics for the periods at which major rings separated from the Loop Current in the decade 2001-2010 compared to the previous time periods, there was no change in the basic statistics on the month in a year when the rings separated from the Loop Current. Table 2 shows that in the case of the entire data set for the period $1972-2010$ as 


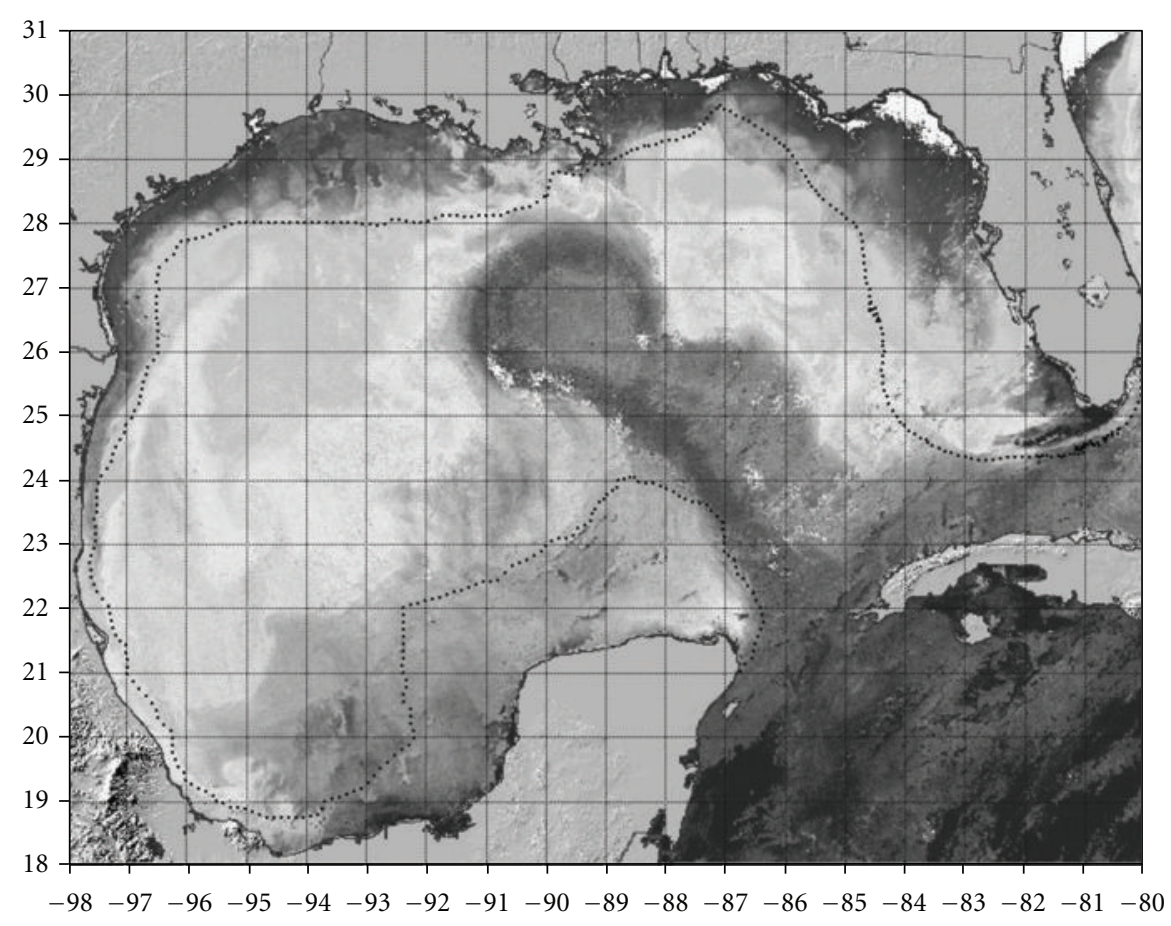

(a)

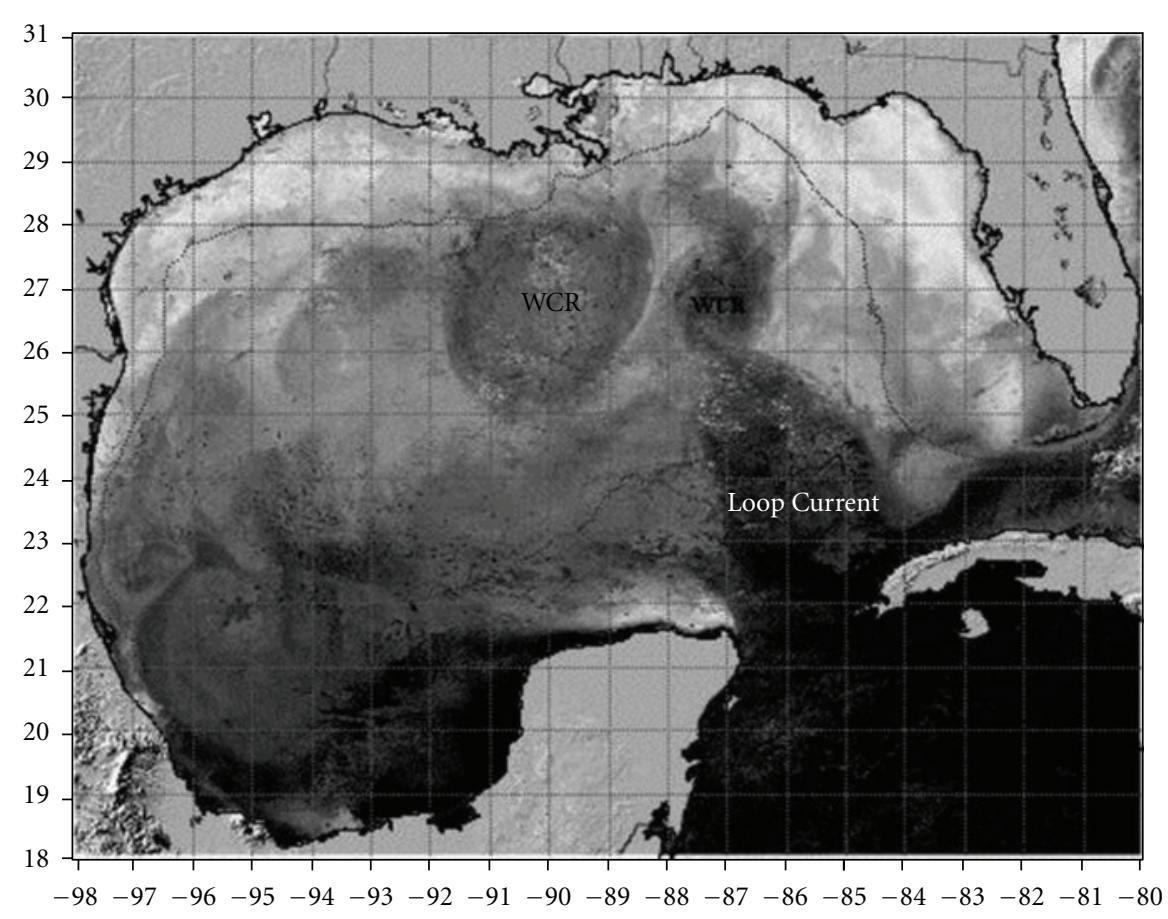

(b)

Figure 7: (a) Sea-surface temperature image from a NOAA satellite for 23 March 2001, showing Loop Current with a significant northwestsoutheast extension. (b) Sea-surface temperature image from a NOAA satellite for 23 April 2001, showing two rings had separated from the Loop Current. 


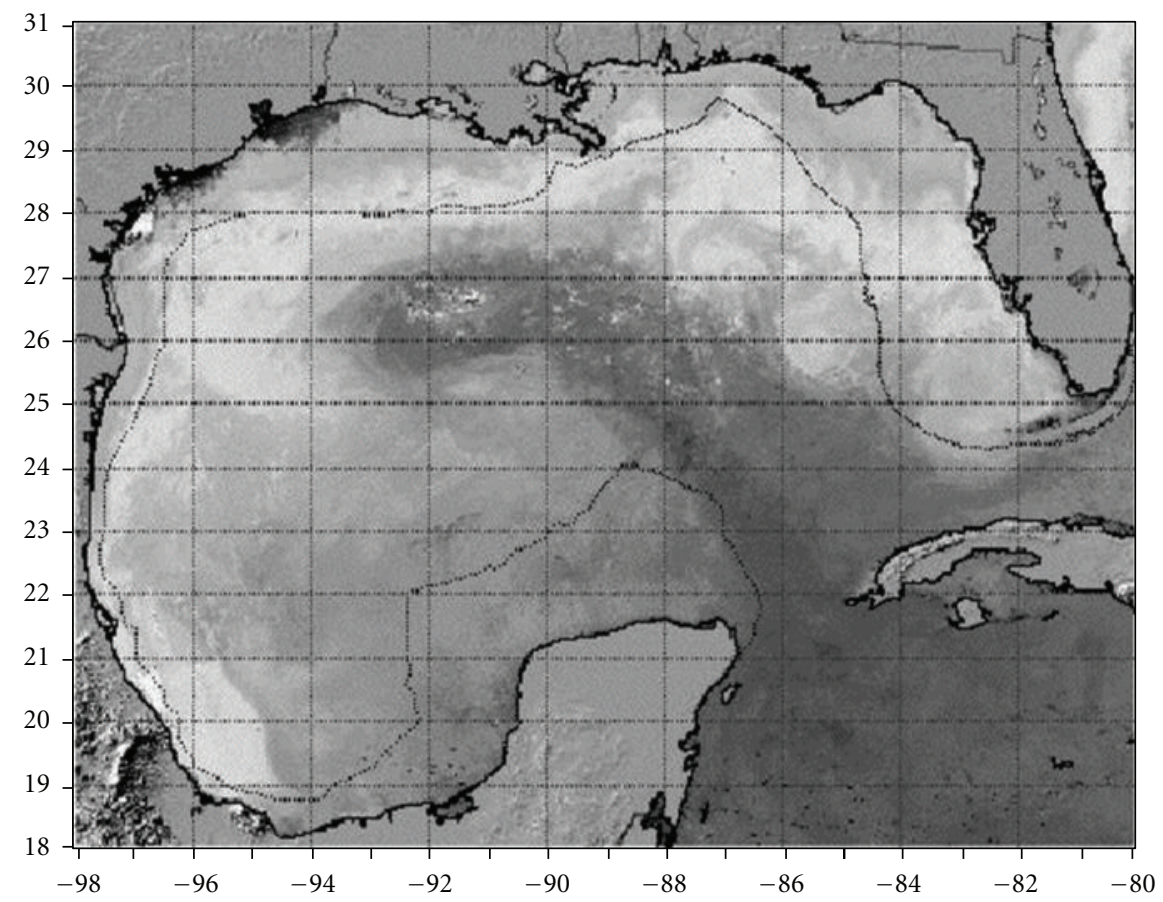

(a)

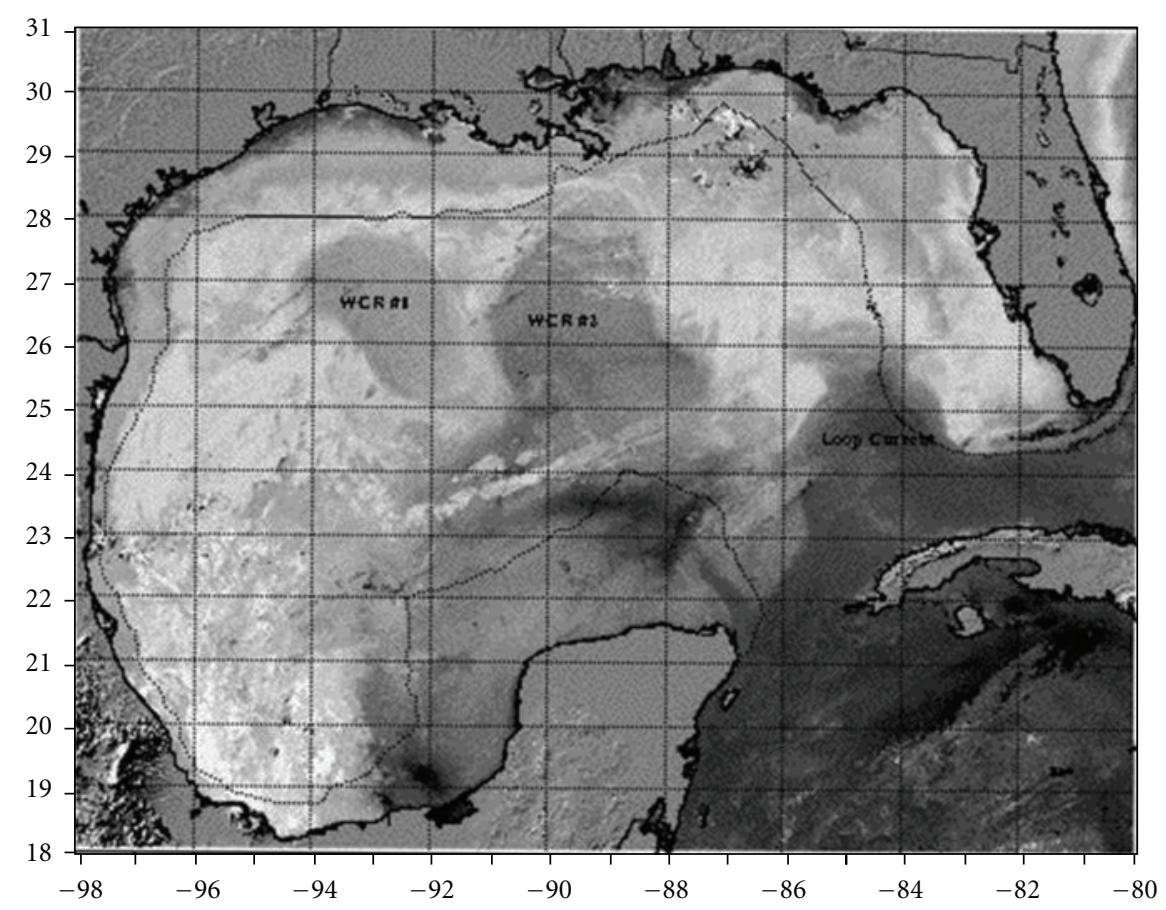

(b)

FIgURE 8: (a) Sea-surface temperature image from a NOAA satellite for 31 January 2002. (b) Sea-surface temperature image from a NOAA satellite for 15 March 2002, showing two rings had separated from the Loop Current.

well as the partitioned data sets for the time periods 19722000 and 2010-2010, the month, on average, when eddyshedding took place was the sixth month (i.e., June) in each case, the standard deviation was \pm 3 months in each case, and the month of the highest number of major ring separations was the third month (i.e., March) in each case. These results are identical to that previously noted for a 32-year data set [6]. 


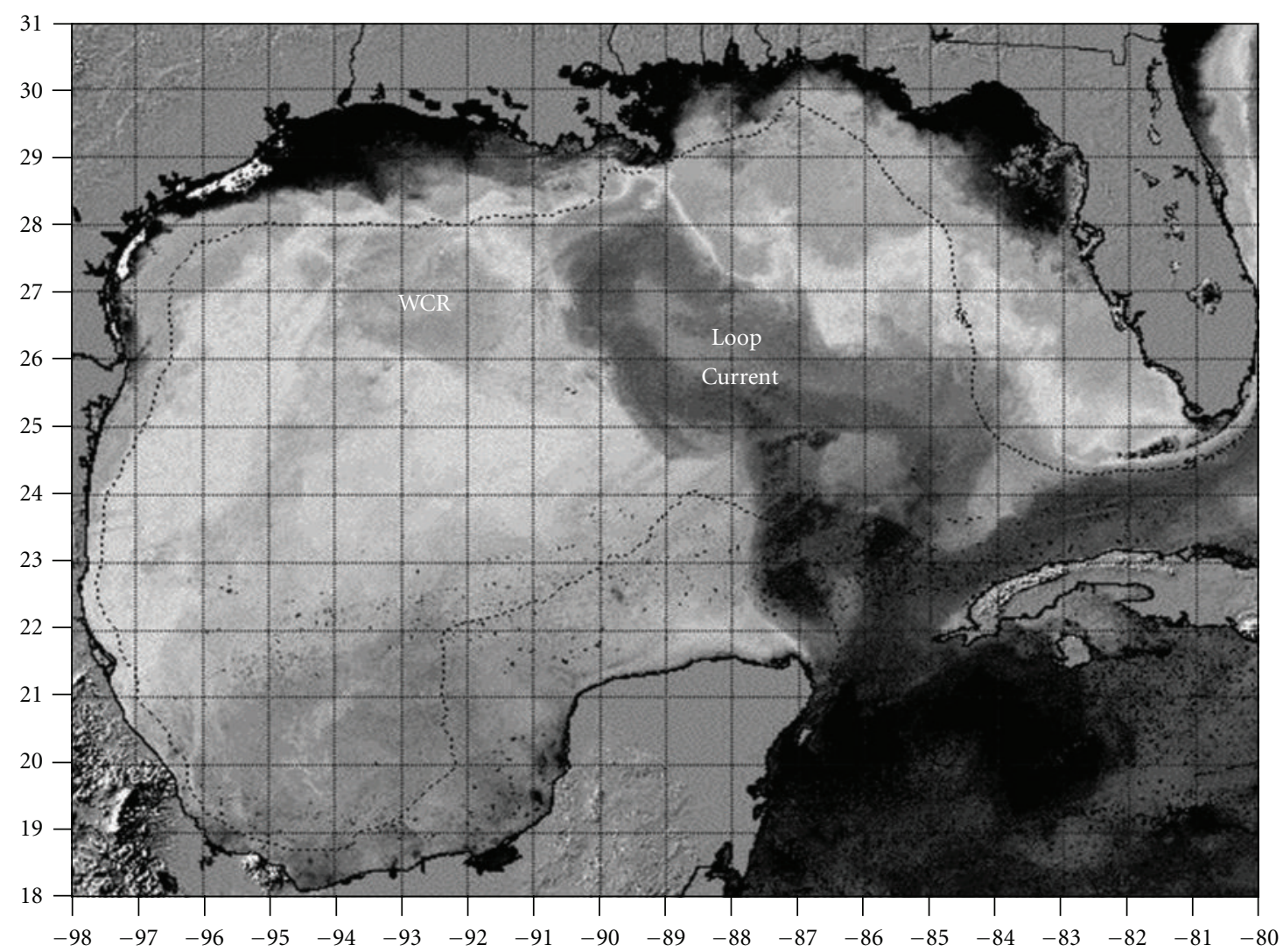

(a)

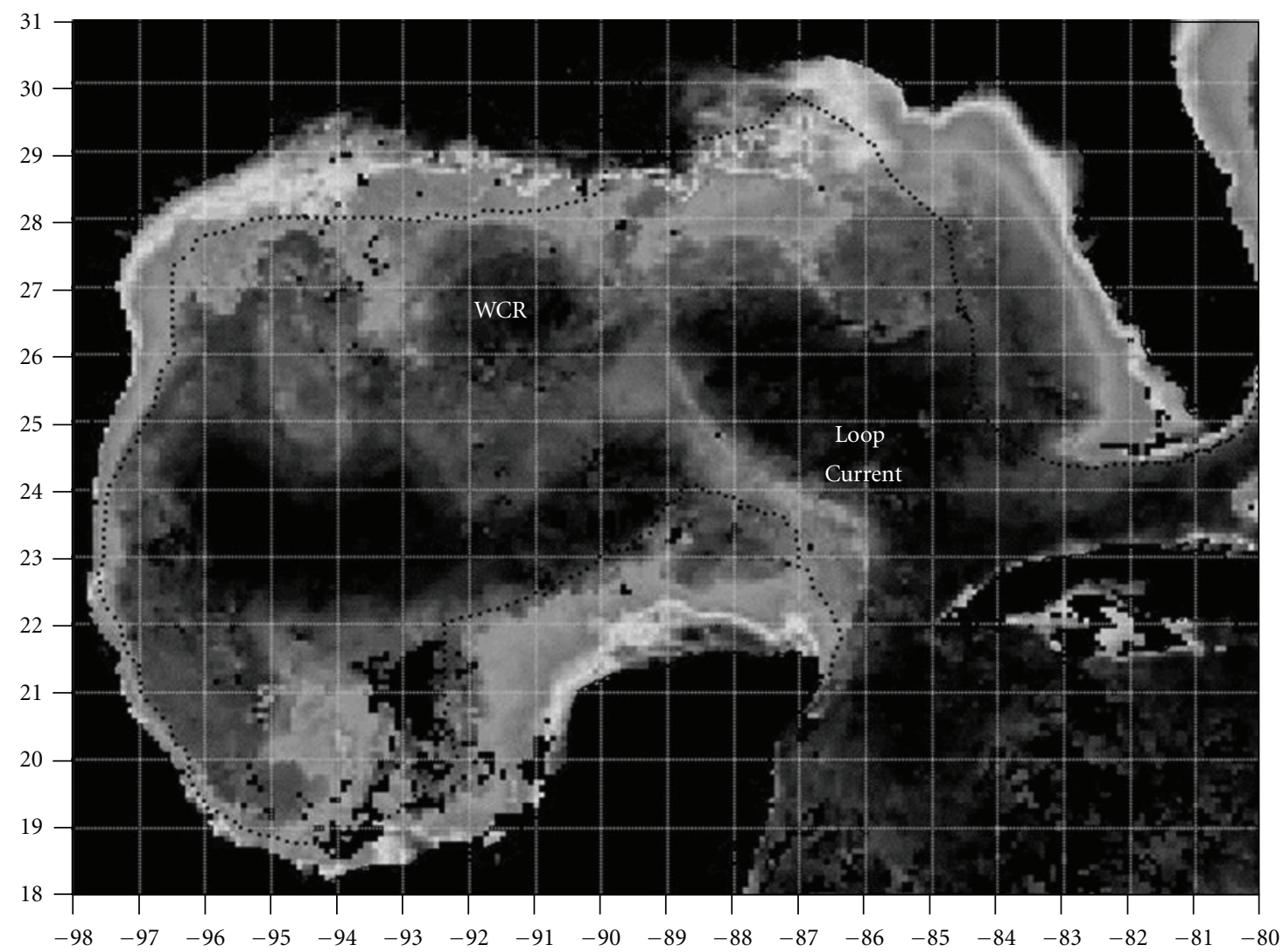

(b)

Figure 9: Continued. 


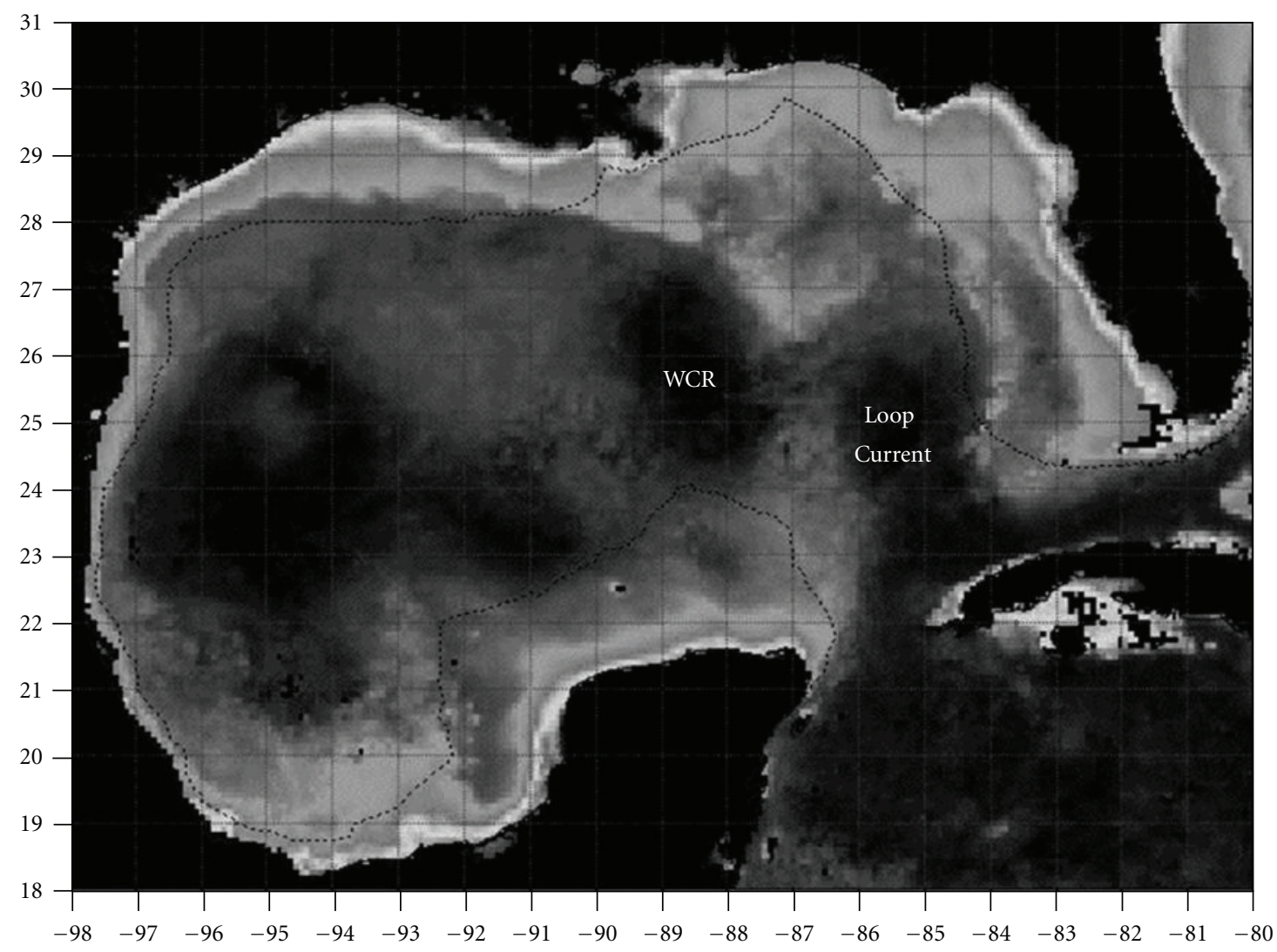

(c)

FIGURE 9: (a) Sea-surface temperature image from a NOAA satellite for 27 February 2006. (b) Average ocean color image from the MODIS satellite centered about 17 June 2006. (c) Average ocean color image from the MODIS satellite centered about 15 October 2006.

TABLE 2: Statistics on major ring separation as a function of the month in a year.

\begin{tabular}{|c|c|c|c|}
\hline Statistic & $\begin{array}{l}\text { Period of } \\
\text { data: } \\
1972-2010\end{array}$ & $\begin{array}{c}\text { Period of } \\
\text { data: } \\
1972-2000\end{array}$ & $\begin{array}{l}\text { Period of } \\
\text { data: } \\
2001-2010\end{array}$ \\
\hline $\begin{array}{l}\text { Average separation } \\
\text { month (month) }\end{array}$ & 6 & 6 & 6 \\
\hline $\begin{array}{l}\text { Standard deviation } \\
\text { for separation month } \\
\text { (month) }\end{array}$ & \pm 3 & \pm 3 & \pm 3 \\
\hline $\begin{array}{l}\text { Mode for separation } \\
\text { month (month) }\end{array}$ & 3 & 3 & 3 \\
\hline
\end{tabular}

The histogram for the Loop Current's eddy shedding as a function of the month in a year for the period 19722010 (Figure 10(a)) shows that most of the rings, about $67 \%$, separated in the winter (i.e., January, February, and March) and summer (i.e., July, August, and September) together (i.e., $33.3 \%$ in each season). The least number of rings separated in the fall (i.e., October, November, and December). The histogram for the period 1972-2000 (Figure 10(b)), on the other hand, shows that about an equal number of rings, about $30 \%$, separated in winter, spring (i.e., April, May, and
June), and summer with the smallest number of separations again in the fall. The histogram for the period 2001-2010 (Figure 10(c)), like that for the entire period, shows that most of the rings, about $75 \%$ in this case, separated in winter and summer (i.e., about $37.5 \%$ in each season) with the least number of separations in the spring and fall. No rings separated in the month 12 (December) in any case. This was previously noted by Vukovich [6].

\section{Loop Current Orientation}

The Loop Current's orientation is a factor associated with the ring separation, and it also had major changes in the decade 2001-2010. Figure 11 presents the variation of the dataset average westward tilt angle for the 21-year period 1990-2010. Like the average eddy-shedding periods given in Figure 3, the value of the average westward tilt angle in Figure 11 is a dataset average, and for 1990, it is the 15-year average from 1976 to 1990 , that for 1991 is the 16-year average from 1976 to 1991 , and so on. In the period 1990 through 2000, the average westward tilt angle varied at most by about $1^{\circ}$, from a low of $15.7^{\circ}$ to a high of about $16.8^{\circ}$. After the year 2000, the westward tilt angle increased by about $5^{\circ}$, reaching a high value of about $20.3^{\circ}$ in 2008 . This indicates that the Loop Current's orientation was, on average, nearer to that when 


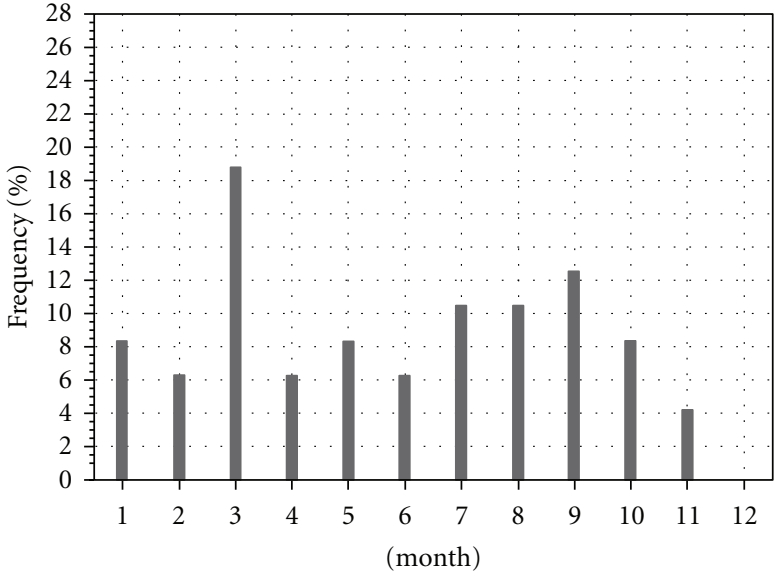

(a)

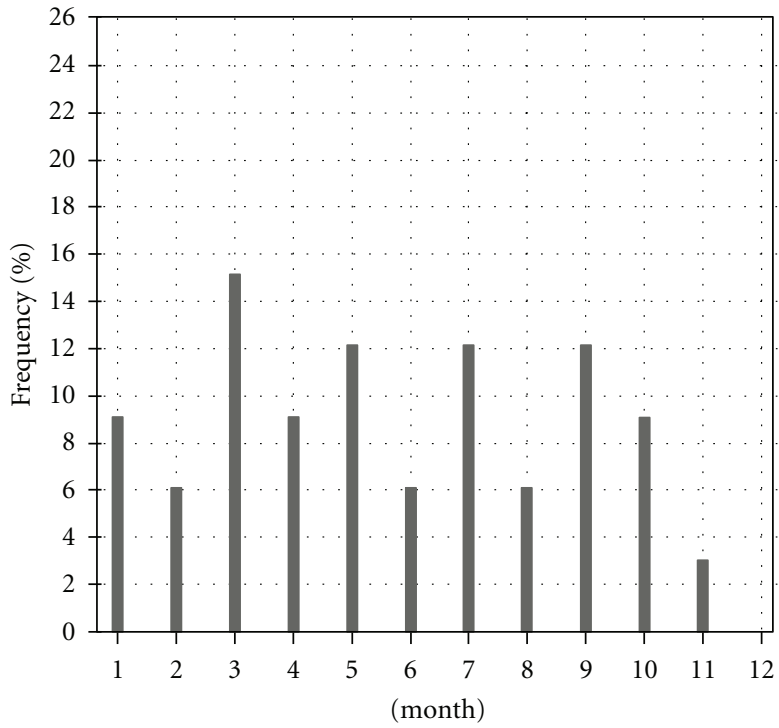

(b)

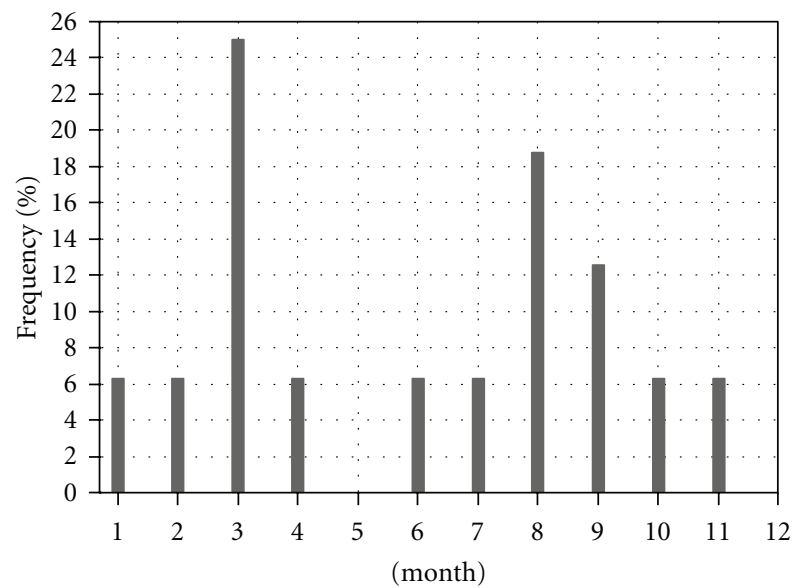

(c)

Figure 10: (a) Histogram of major ring separation from the Loop Current as a function of month in a year for the period 1972-2010. The total number of events is 47. (b) Histogram of major ring separation from the Loop Current as a function of month in a year for the period 1972-2000. The total number of events is 31. (c) Histogram of major ring separation from the Loop Current as a function of month in a year for the period 2001-2010. The total number of events is 16 .

ring separation normally occurs (i.e., orientation angles of $30^{\circ}$ or more) during that decade and was more inclined to have ring separation in that period than before 2001.

In order for the dataset average westward tilt angle to increase in this manner, very large monthly values of the orientation angle persisted in the 2001-2010 period. As a matter of fact in the first two years of that period (i.e., 2001 and 2002), very large westward tilt angles were documented for the Loop Current associated with the remarkable westward extension of the Loop Current (Figures 7(a) and 8(a)). The Loop Current had about northwest-southeast orientation and extended as far west as $93^{\circ} \mathrm{W}$ longitude. The westward tilt angle noted for the 2001 event was $53^{\circ}$ and that for the 2002 event $63^{\circ}$. Examination of the satellite remote sensing data archives as far back as 1972 and the literature, which provides analyses of the Loop Current using ship survey data, as far back as 1932, indicated that a Loop Current having both large westward extensions and large westward tilt angles had not occurred previously. The largest westward tilt angle observed prior to 2001 was $59^{\circ}$, but in that case, there was no large westward extension of the Loop Current.

For the period 1976 through 2000, the average orientation angle was $16.5^{\circ}$, the standard deviation was $\pm 14.0^{\circ}$, and the mode for that dataset was $0^{\circ}$ (Table 3 ). The range in the orientation angle data set was $0^{\circ}$ to $59^{\circ}$. Approximately $86 \%$ of the angles were $<30^{\circ}$, indicating that the Loop Current was most often in a mode over that period in which eddy shedding would not occur. In the decade 2001 through 2010, the average orientation angle was $26.4^{\circ}$, about $10^{\circ}$ higher than that for the period 1776 through 2000 and about $9^{\circ}$ higher than the two previous decades (i.e., the average for the decade 1981-1990 was $16.5^{\circ}$ and that for the decade $1991-2000$ was 


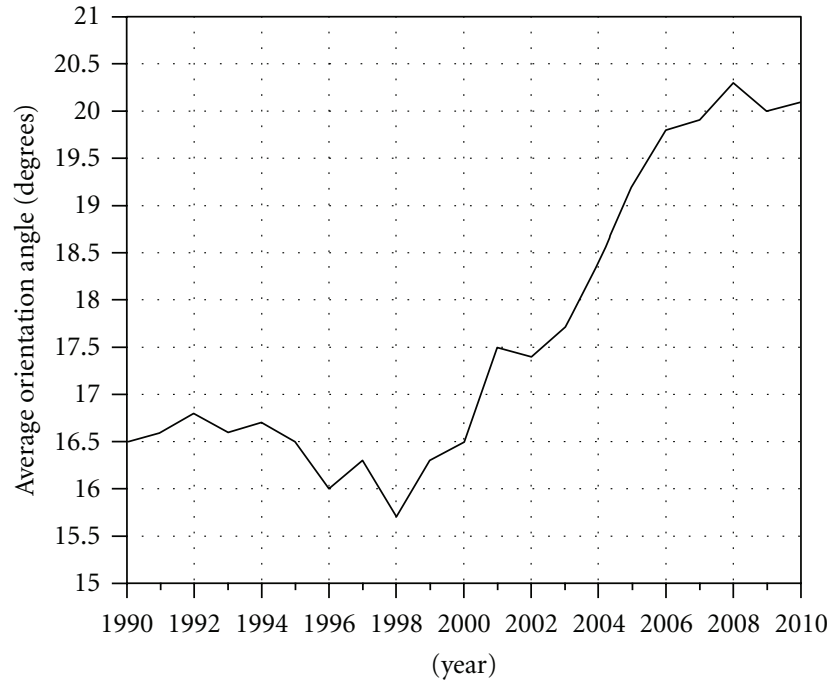

Figure 11: The average Loop Current westward tilt angle for the period 1990-2010. The average value for 1990 is the 15-year average from 1976 to 1990, that for 1991 is the 16-year average from 1976 to 1991, and so on.

Table 3: Statistics on the Loop Current's Orientation Angle for Various Periods of Time.

\begin{tabular}{|c|c|c|c|}
\hline Statistic & $\begin{array}{c}\text { All data } \\
(1976-2010)\end{array}$ & $\begin{array}{c}\text { Data before } \\
2001 \\
(1976-2000)\end{array}$ & $\begin{array}{c}\text { Data since } \\
2000 \\
(2001-2010)\end{array}$ \\
\hline $\begin{array}{l}\text { Average orientation } \\
\text { angle }\end{array}$ & $20.1^{\circ}$ & $16.5^{\circ}$ & $26.4^{\circ}$ \\
\hline $\begin{array}{l}\text { Standard deviation of } \\
\text { orientation angle }\end{array}$ & $15.0^{\circ}$ & $14.0^{\circ}$ & $16.9^{\circ}$ \\
\hline Mode & $0^{\circ}$ & $0^{\circ}$ & $0^{\circ}$ \\
\hline Maximum angle & $63^{\circ}$ & $59^{\circ}$ & $63^{\circ}$ \\
\hline Minimum angle & $0^{\circ}$ & $0^{\circ}$ & $0^{\circ}$ \\
\hline $\begin{array}{l}\text { Percentage of data with } \\
\text { orientation angles }<30^{\circ}\end{array}$ & $75 \%$ & $86 \%$ & $54 \%$ \\
\hline $\begin{array}{l}\text { Percentage of data with } \\
\text { orientation angles } \geq 30^{\circ}\end{array}$ & $25 \%$ & $14 \%$ & $46 \%$ \\
\hline
\end{tabular}

$16.6^{\circ}$ ). In the decade 2001 through 2010 , approximately $54 \%$ of the angles were $<30^{\circ}$ or $46 \%$ were $\geq 30^{\circ}$. In the two decades prior to 2001 (i.e., the decades 1981-1990 and 1991-2000), only $14 \%$ of the orientation angles were $\geq 30^{\circ}$ in each decade. In the decade 2001-2010, the Loop Current was in a state where it was just as likely to shed an eddy as not.

\section{Summary and Discussion}

The major findings of this study are itemized below.

(a) The dataset average period for ring separation decreased by about 1 month in the decade 20012010. The 39-year average (1972-2010) was about 10 months. The average over the 29-year period 1972 2000 was about 11 months.
TABLE 4: The eddy-separation period and the month in which eddy separation took place for each year. also provided is the data sources used to determine the month of separation.

\begin{tabular}{|c|c|c|c|}
\hline Year & $\begin{array}{c}\text { Separation period } \\
\text { (months) }\end{array}$ & $\begin{array}{l}\text { Separation } \\
\text { month }\end{array}$ & $\begin{array}{c}\text { Data used in } \\
\text { determination of period }\end{array}$ \\
\hline 1972 & $\bullet$ & 5 & SST \\
\hline 1973 & 14 & 7 & SOP \\
\hline 1974 & 9 & 4 & SST \\
\hline 1975 & 9 & 1 & SST \\
\hline 1975 & 6 & 7 & SOP \\
\hline 1976 & 13 & 8 & SOP \\
\hline 1977 & 7 & 3 & SST \\
\hline 1978 & 15 & 6 & SST, SOP \\
\hline 1979 & 10 & 4 & SST \\
\hline 1980 & 9 & 1 & SST \\
\hline 1981 & 14 & 3 & SST \\
\hline 1982 & 14 & 5 & SST, OCD \\
\hline 1983 & 10 & 3 & SST \\
\hline 1984 & 11 & 2 & SST \\
\hline 1985 & 17 & 7 & SST, OCD, SOP \\
\hline 1986 & 8 & 1 & SST \\
\hline 1986 & 9 & 10 & SST \\
\hline 1987 & 13 & 11 & SST \\
\hline 1988 & 6 & 5 & SST \\
\hline 1989 & 12 & 5 & SST \\
\hline 1990 & 16 & 9 & SOP \\
\hline 1991 & 12 & 9 & SOP \\
\hline 1992 & 10 & 7 & SOP \\
\hline 1993 & 11 & 6 & SOP, SST \\
\hline 1994 & 15 & 9 & SSH, SOP \\
\hline 1995 & 6 & 3 & SST, SSH \\
\hline 1995 & 6 & 9 & SSH, SOP \\
\hline 1996 & 5 & 2 & SST, SSH \\
\hline 1996 & 11 & 8 & SSH, SOP \\
\hline 1997 & 14 & 10 & SST, SSH \\
\hline 1998 & 6 & 3 & SST, SSH \\
\hline 1999 & 19 & 10 & SST, SSH \\
\hline 2001 & 18 & 4 & SST, OCD, SSH \\
\hline 2002 & 11 & 3 & SST, OCD, SSH \\
\hline 2002 & 11 & 3 & SST, OCD, SSH \\
\hline 2003 & 17 & 8 & OCD, SSH \\
\hline 2004 & 5 & 1 & SST, OCD, SSH \\
\hline 2004 & 8 & 9 & OCD, SSH \\
\hline 2005 & 12 & 9 & OCD, SSH \\
\hline 2006 & 5 & 2 & SST, OCD, SSH \\
\hline 2006 & 4 & 6 & SST, OCD, SSH \\
\hline 2006 & 4 & 10 & SST, OCD, SSH \\
\hline 2007 & 13 & 11 & SST, OCD, SSH \\
\hline 2008 & 4 & 3 & SST, OCD, SSH \\
\hline
\end{tabular}


TABle 4: Continued.

\begin{tabular}{cccc}
\hline Year & $\begin{array}{c}\text { Separation period } \\
\text { (months) }\end{array}$ & $\begin{array}{c}\text { Separation } \\
\text { month }\end{array}$ & $\begin{array}{c}\text { Data used in } \\
\text { determination of period }\end{array}$ \\
\hline 2008 & 5 & 8 & OCD, SSH \\
2009 & 7 & 3 & SST, OCD, SSH \\
2009 & 4 & 7 & OCD, SSH \\
2010 & 13 & 8 & OCD, SSH \\
\hline
\end{tabular}

SST: Sea-Surface Temperature from Satellite Infrared Water Vapor Window Data.

OCD: Satellite Ocean Color Data from CZCS (1979-1985) or from MODIS (2000-Present).

SSH: Sea-Surface Height from Various Satellite (1991-present).

SOP: Data and/or Information Obtained from the MMS's Ship-of-Opportunity Program, MMS sponsored Field Programs, and/or Field Programs Sponsored by Various Oil and Gas Companies.

(b) Sixteen (16) WCRs separated from the Loop Current in the decade 2001-2010, whereas in two previous decades, 11 WCRs separated in each decade.

(c) The average ring-separation period in decade 20012010 was about 9 months, and in the decades 19811990 and 1991-2000, the average period for ring separation in each decade was about 11 months.

(d) More than half the rings (i.e., 56\%) that separated from the Loop Current in the decade 2001-2010 had separation periods $\leq 8$ months. In the period 19722000 , only $26 \%$ of the rings had separation periods $\leq 8$ months, with $18 \%$ in the period $1981-1990$ and $36 \%$ in the period 1991-2000 having eddy separation periods $\leq 8$ months.

(e) The period 2001-2010 was characterized with 5 years in which more than one major eddy separated in each year. In four of those years, two major rings separated from the Loop Current, and in one of those years, two major rings separated from the Loop Current simultaneously. In the other year, three major rings separated from the Loop current during that year at different times. Previous to 2001, so many multiple events were not observed in a decade.

(f) The dataset average of the Loop Current's westward tilt angle increased by about $5^{\circ}$ from 1998 to 2008.

(g) The dataset average of the Loop Current's westward tilt angle was about $17^{\circ}$ in the period 1976-2000 and about $20^{\circ}$ in the period $1972-2010$.

(h) The average westward tilt angle for the decade 20012010 was about $26^{\circ}$. In the decades $1981-1990$ and 1991-2000, the average westward tilt angle was about $17^{\circ}$ in each decade.

(i) In the period 1976-2000, the Loop Current's westward tilt angle was $>30^{\circ}$ (i.e., when the average Loop Current's westward tilt angle reaches a value $>30^{\circ}$, ring separation normally occurs within 30-60 days) about $14 \%$ of the time, which characterizes a Loop Current in which ring separation was, on average, not imminent and/or occurred often. It was $>30^{\circ}$ about $25 \%$ in the period $1976-2010$.
TABLE 5: Orientation angle as a function of month and year.

\begin{tabular}{|c|c|}
\hline Year and month & Orientation angle \\
\hline \multicolumn{2}{|l|}{1976} \\
\hline Jan & 27 \\
\hline $\mathrm{Feb}$ & 24 \\
\hline Mar & 0 \\
\hline Apr & 13 \\
\hline May & 29 \\
\hline Jun & No Data \\
\hline Jul & No Data \\
\hline Aug & No Data \\
\hline Sep & No Data \\
\hline Oct & No Data \\
\hline Nov & 9 \\
\hline Dec & 14 \\
\hline \multicolumn{2}{|l|}{1977} \\
\hline Jan & 20 \\
\hline Feb & 14 \\
\hline Mar & 0 \\
\hline Apr & 0 \\
\hline May & 0 \\
\hline Jun & No Data \\
\hline Jul & No Data \\
\hline Aug & No Data \\
\hline Sep & No Data \\
\hline Oct & No Data \\
\hline Nov & 0 \\
\hline Dec & 15 \\
\hline \multicolumn{2}{|l|}{1978} \\
\hline Jan & 9 \\
\hline Feb & 27 \\
\hline Mar & 26 \\
\hline Apr & 28 \\
\hline May & 21 \\
\hline Jun & No Data \\
\hline Jul & No Data \\
\hline Aug & No Data \\
\hline Sep & No Data \\
\hline Oct & No Data \\
\hline Nov & 0 \\
\hline Dec & 14 \\
\hline \multicolumn{2}{|l|}{1979} \\
\hline Jan & 19 \\
\hline Feb & 21 \\
\hline Mar & 29 \\
\hline Apr & 24 \\
\hline May & 42 \\
\hline Jun & No Data \\
\hline Jul & No Data \\
\hline Aug & No Data \\
\hline Sep & No Data \\
\hline
\end{tabular}


TABle 5: Continued.

\begin{tabular}{|c|c|}
\hline Year and month & Orientation angle \\
\hline Oct & No Data \\
\hline Nov & 30 \\
\hline Dec & 53 \\
\hline \multicolumn{2}{|l|}{1980} \\
\hline Jan & 31 \\
\hline Feb & 7 \\
\hline Mar & 13 \\
\hline Apr & 13 \\
\hline May & 0 \\
\hline Jun & No Data \\
\hline Jul & No Data \\
\hline Aug & No Data \\
\hline Sep & No Data \\
\hline Oct & No Data \\
\hline Nov & 14 \\
\hline Dec & 10 \\
\hline \multicolumn{2}{|l|}{1981} \\
\hline Jan & 27 \\
\hline Feb & 19 \\
\hline Mar & 3 \\
\hline Apr & 4 \\
\hline May & 0 \\
\hline Jun & No Data \\
\hline Jul & No Data \\
\hline Aug & No Data \\
\hline Sep & No Data \\
\hline Oct & No Data \\
\hline Nov & 2 \\
\hline Dec & 11 \\
\hline \multicolumn{2}{|l|}{1982} \\
\hline Jan & 16 \\
\hline Feb & 11 \\
\hline Mar & 13 \\
\hline Apr & 21 \\
\hline May & 22 \\
\hline Jun & No Data \\
\hline Jul & No Data \\
\hline Aug & No Data \\
\hline Sep & No Data \\
\hline Oct & No Data \\
\hline Nov & 14 \\
\hline Dec & 24 \\
\hline \multicolumn{2}{|l|}{1983} \\
\hline Jan & 35 \\
\hline Feb & 32 \\
\hline Mar & 29 \\
\hline Apr & 19 \\
\hline May & 18 \\
\hline Jun & No Data \\
\hline
\end{tabular}

TABle 5: Continued.

\begin{tabular}{|c|c|}
\hline Year and month & Orientation angle \\
\hline Jul & No Data \\
\hline Aug & No Data \\
\hline Sep & No Data \\
\hline Oct & No Data \\
\hline Nov & 24 \\
\hline Dec & 26 \\
\hline \multicolumn{2}{|l|}{1984} \\
\hline Jan & 21 \\
\hline Feb & 30 \\
\hline Mar & 29 \\
\hline Apr & 4 \\
\hline May & 8 \\
\hline Jun & 5 \\
\hline Jul & 10 \\
\hline Aug & 19 \\
\hline Sep & No Data \\
\hline Oct & No Data \\
\hline Nov & 7 \\
\hline Dec & 3 \\
\hline \multicolumn{2}{|l|}{1985} \\
\hline Jan & 39 \\
\hline Feb & 10 \\
\hline Mar & 15 \\
\hline Apr & 29 \\
\hline May & 24 \\
\hline Jun & 37 \\
\hline Jul & No Data \\
\hline Aug & No Data \\
\hline Sep & 5 \\
\hline Oct & 11 \\
\hline Nov & 36 \\
\hline Dec & 32 \\
\hline \multicolumn{2}{|l|}{1986} \\
\hline Jan & 6 \\
\hline Feb & 0 \\
\hline Mar & 19 \\
\hline Apr & 29 \\
\hline May & 26 \\
\hline Jun & 20 \\
\hline Jul & 24 \\
\hline Aug & No Data \\
\hline Sep & No Data \\
\hline Oct & No Data \\
\hline Nov & 0 \\
\hline Dec & 0 \\
\hline \multicolumn{2}{|l|}{1987} \\
\hline Jan & 4 \\
\hline Feb & 11 \\
\hline Mar & 24 \\
\hline
\end{tabular}


Table 5: Continued.

\begin{tabular}{|c|c|}
\hline Year and month & Orientation angle \\
\hline Apr & 20 \\
\hline May & 20 \\
\hline Jun & 20 \\
\hline Jul & No Data \\
\hline Aug & No Data \\
\hline Sep & No Data \\
\hline Oct & No Data \\
\hline Nov & 0 \\
\hline Dec & 0 \\
\hline \multicolumn{2}{|l|}{1988} \\
\hline Jan & 0 \\
\hline Feb & 18 \\
\hline Mar & 4 \\
\hline Apr & 14 \\
\hline May & 0 \\
\hline Jun & 0 \\
\hline Jul & No Data \\
\hline Aug & No Data \\
\hline Sep & No Data \\
\hline Oct & No Data \\
\hline Nov & 16 \\
\hline Dec & 17 \\
\hline \multicolumn{2}{|l|}{1989} \\
\hline Jan & 33 \\
\hline Feb & 34 \\
\hline Mar & 29 \\
\hline Apr & 32 \\
\hline May & 0 \\
\hline Jun & 0 \\
\hline Jul & No Data \\
\hline Aug & No Data \\
\hline Sep & No Data \\
\hline Oct & No Data \\
\hline Nov & 29 \\
\hline Dec & 8 \\
\hline \multicolumn{2}{|l|}{1990} \\
\hline Jan & 40 \\
\hline Feb & 12 \\
\hline Mar & 15 \\
\hline Apr & 15 \\
\hline May & 20 \\
\hline Jun & 30 \\
\hline Jul & No Data \\
\hline Aug & No Data \\
\hline Sep & No Data \\
\hline Oct & No Data \\
\hline Nov & 0 \\
\hline Dec & 0 \\
\hline 1991 & \\
\hline
\end{tabular}

Table 5: Continued.

\begin{tabular}{|c|c|}
\hline Year and month & Orientation angle \\
\hline Jan & 25 \\
\hline Feb & 8 \\
\hline Mar & 31 \\
\hline Apr & 17 \\
\hline May & 13 \\
\hline Jun & No Data \\
\hline Jul & No Data \\
\hline Aug & No Data \\
\hline Sep & No Data \\
\hline Oct & 18 \\
\hline Nov & 14 \\
\hline Dec & 24 \\
\hline \multicolumn{2}{|l|}{1992} \\
\hline Jan & 10 \\
\hline Feb & 27 \\
\hline Mar & 3 \\
\hline Apr & 24 \\
\hline May & 29 \\
\hline Jun & 45 \\
\hline Jul & Missing \\
\hline Aug & Missing \\
\hline Sep & Missing \\
\hline Oct & 0 \\
\hline Nov & 0 \\
\hline Dec & 33 \\
\hline \multicolumn{2}{|l|}{1993} \\
\hline Jan & 25 \\
\hline Feb & 1 \\
\hline Mar & 24 \\
\hline Apr & 30 \\
\hline May & 0 \\
\hline Jun & 0 \\
\hline Jul & Missing \\
\hline Aug & Missing \\
\hline Sep & Missing \\
\hline Oct & Missing \\
\hline Nov & 0 \\
\hline Dec & 22 \\
\hline \multicolumn{2}{|l|}{1994} \\
\hline Jan & 27 \\
\hline Feb & 26 \\
\hline Mar & 30 \\
\hline Apr & 14 \\
\hline May & 25 \\
\hline Jun & 10 \\
\hline Jul & 34 \\
\hline Aug & Missing \\
\hline Sep & Missing \\
\hline Oct & 5 \\
\hline
\end{tabular}


TABle 5: Continued.

\begin{tabular}{|c|c|}
\hline Year and month & Orientation angle \\
\hline Nov & 0 \\
\hline Dec & 22 \\
\hline \multicolumn{2}{|l|}{1995} \\
\hline Jan & 21 \\
\hline Feb & 23 \\
\hline Mar & 3 \\
\hline Apr & 4 \\
\hline May & 2 \\
\hline Jun & 24 \\
\hline Jul & Missing \\
\hline Aug & Missing \\
\hline Sep & Missing \\
\hline Oct & 11 \\
\hline Nov & 6 \\
\hline Dec & 16 \\
\hline \multicolumn{2}{|l|}{1996} \\
\hline Jan & 23 \\
\hline Feb & 31 \\
\hline Mar & 2 \\
\hline Apr & 7 \\
\hline May & 9 \\
\hline Jun & 23 \\
\hline Jul & 13 \\
\hline Aug & 1 \\
\hline Sep & 1 \\
\hline Oct & 1 \\
\hline Nov & 1 \\
\hline Dec & 0 \\
\hline \multicolumn{2}{|l|}{1997} \\
\hline Jan & 17 \\
\hline Feb & 22 \\
\hline Mar & 18 \\
\hline Apr & 16 \\
\hline May & 17 \\
\hline Jun & Missing \\
\hline Jul & 18 \\
\hline Aug & Missing \\
\hline Sep & 34 \\
\hline Oct & 49 \\
\hline Nov & 3 \\
\hline Dec & 17 \\
\hline \multicolumn{2}{|l|}{1998} \\
\hline Jan & 14 \\
\hline Feb & 15 \\
\hline Mar & 29 \\
\hline Apr & 0 \\
\hline May & 10 \\
\hline Jun & 2 \\
\hline Jul & 0 \\
\hline
\end{tabular}

TABLE 5: Continued.

\begin{tabular}{|c|c|}
\hline Year and month & Orientation angle \\
\hline Aug & 23 \\
\hline Sep & 0 \\
\hline Oct & 0 \\
\hline Nov & 0 \\
\hline Dec & 0 \\
\hline \multicolumn{2}{|l|}{1999} \\
\hline Jan & 4 \\
\hline Feb & 7 \\
\hline Mar & 11 \\
\hline Apr & 42 \\
\hline May & 21 \\
\hline Jun & 51 \\
\hline Jul & 40 \\
\hline Aug & 59 \\
\hline Sep & 27 \\
\hline Oct & 26 \\
\hline Nov & 0 \\
\hline Dec & 23 \\
\hline \multicolumn{2}{|l|}{2000} \\
\hline Jan & 10 \\
\hline Feb & 21 \\
\hline Mar & 14 \\
\hline Apr & 14 \\
\hline May & 22 \\
\hline Jun & 22 \\
\hline Jul & 28 \\
\hline Aug & 12 \\
\hline Sep & 14 \\
\hline Oct & 35 \\
\hline Nov & 29 \\
\hline Dec & 21 \\
\hline \multicolumn{2}{|l|}{2001} \\
\hline Jan & 39 \\
\hline Feb & 40 \\
\hline Mar & 53 \\
\hline Apr & 44 \\
\hline May & 28 \\
\hline Jun & 9 \\
\hline Jul & 18 \\
\hline Aug & 44 \\
\hline Sep & 45 \\
\hline Oct & 41 \\
\hline Nov & 39 \\
\hline Dec & 21 \\
\hline \multicolumn{2}{|l|}{2002} \\
\hline Jan & 63 \\
\hline Feb & 46 \\
\hline Mar & 40 \\
\hline Apr & 0 \\
\hline
\end{tabular}


TABle 5: Continued.

\begin{tabular}{|c|c|}
\hline Year and month & Orientation angle \\
\hline May & 0 \\
\hline Jun & 0 \\
\hline Jul & 0 \\
\hline Aug & 0 \\
\hline Sep & 0 \\
\hline Oct & 0 \\
\hline Nov & 0 \\
\hline Dec & 40 \\
\hline \multicolumn{2}{|l|}{2003} \\
\hline Jan & 22 \\
\hline Feb & 7 \\
\hline Mar & 18 \\
\hline Apr & 32 \\
\hline May & 48 \\
\hline Jun & 39 \\
\hline Jul & 30 \\
\hline Aug & 36 \\
\hline Sep & 10 \\
\hline Oct & 29 \\
\hline Nov & 0 \\
\hline Dec & 0 \\
\hline \multicolumn{2}{|l|}{2004} \\
\hline Jan & 63 \\
\hline Feb & 24 \\
\hline Mar & 21 \\
\hline Apr & 28 \\
\hline May & 34 \\
\hline Jun & 31 \\
\hline Jul & 29 \\
\hline Aug & 32 \\
\hline Sep & 47 \\
\hline Oct & 30 \\
\hline Nov & 34 \\
\hline Dec & 25 \\
\hline \multicolumn{2}{|l|}{2005} \\
\hline Jan & 30 \\
\hline Feb & 26 \\
\hline Mar & 36 \\
\hline Apr & 37 \\
\hline May & 30 \\
\hline Jun & 46 \\
\hline Jul & 48 \\
\hline Aug & 48 \\
\hline Sep & 40 \\
\hline Oct & 48 \\
\hline Nov & 36 \\
\hline Dec & 36 \\
\hline \multicolumn{2}{|l|}{2006} \\
\hline Jan & 50 \\
\hline
\end{tabular}

Table 5: Continued.

\begin{tabular}{|c|c|}
\hline Year and month & Orientation angle \\
\hline Feb & 40 \\
\hline Mar & 17 \\
\hline Apr & 39 \\
\hline May & 26 \\
\hline Jun & 28 \\
\hline Jul & 36 \\
\hline Aug & 55 \\
\hline Sep & 58 \\
\hline Oct & 17 \\
\hline Nov & 10 \\
\hline Dec & 28 \\
\hline \multicolumn{2}{|l|}{2007} \\
\hline Jan & 0 \\
\hline Feb & 22 \\
\hline Mar & 28 \\
\hline Apr & 20 \\
\hline May & 24 \\
\hline Jun & 14 \\
\hline Jul & 25 \\
\hline Aug & 33 \\
\hline Sep & 40 \\
\hline Oct & 46 \\
\hline Nov & 0 \\
\hline Dec & 9 \\
\hline \multicolumn{2}{|l|}{2008} \\
\hline Jan & 30 \\
\hline Feb & 27 \\
\hline Mar & 42 \\
\hline Apr & 33 \\
\hline May & 26 \\
\hline Jun & 44 \\
\hline Jul & 30 \\
\hline Aug & 30 \\
\hline Sep & 0 \\
\hline Oct & 28 \\
\hline Nov & 28 \\
\hline Dec & 40 \\
\hline \multicolumn{2}{|l|}{2009} \\
\hline Jan & 40 \\
\hline Feb & 44 \\
\hline Mar & 0 \\
\hline Apr & 26 \\
\hline May & 25 \\
\hline Jun & 3 \\
\hline Jul & 0 \\
\hline Aug & 0 \\
\hline Sep & 0 \\
\hline Oct & 0 \\
\hline Nov & 0 \\
\hline
\end{tabular}


TABle 5: Continued.

\begin{tabular}{cc}
\hline Year and month & Orientation angle \\
\hline Dec & 22 \\
2010 & \\
Jan & 37 \\
Feb & 8 \\
Mar & 15 \\
Apr & 15 \\
May & 28 \\
Jun & 45 \\
Jul & 53 \\
Aug & 0 \\
Sep & 0 \\
Oct & 23 \\
Nov & 0 \\
Dec & 25 \\
\hline
\end{tabular}

(j) In the two decades prior to 2001 (i.e., the decades 1981-1990 and 1991-2000), the Loop Current's westward tilt angle was $>30^{\circ}$ about $14 \%$ of the time in each decade. In the period 2001-2010, the Loop Current's westward tilt angle was $>30^{\circ}$ about $46 \%$ of the time, which characterizes a Loop Current in which eddy separation would occur sooner than in the years prior to 2001 and would occurr more often.

These observations suggest that a major change has occurred in the forcing function for Loop Current eddy shedding in the period 2001-2010. Oey et al. [10] provided significant information on the probable forcing functions for Loop Current ring separation. They used a numerical model to show that there are three principal forcing functions that cause WCRs to separate from the Loop Current: (1) steady transport in the Yucatan Strait; (2) Caribbean eddies (i.e., anticyclones) that "squeeze" through the Yucatan Strait; (3) wind-induced transport fluctuations through the Greater Antilles Passages. Their model shed Loop Current eddies with periods of about 9 months to 10 months with a steady transport in the Yucatan Strait. Caribbean eddies produced ring separation in their model with longer periods (i.e., on the order of about 14 to 16 months). Caribbean eddies tended to hinder the northward extension of the Loop Current into the EGOM, which led to longer periods between eddy separations. Caribbean eddies are anticyclonic eddies, which are produced in the North Brazil Current [11]. These rings grow as they travel westward. Murphy et al. [12] showed that the Caribbean eddies travel westward with an average speed of about $15 \mathrm{~cm} \mathrm{~s}^{-1}$ and that it took most eddies 10 months to travel from the Lesser Antilles to the Yucatan Channel.

The modeling results of Oey et al. [10] indicated that wind-induced transport fluctuations through the Greater Antilles Passages caused Loop Current eddy shedding with substantially shorter periods: periods from 3 months to 7 months. Since the decade 2001-2010 was characterized with considerably more Loop Current ring separations with periods $\leq 8$ months than in prior decades, this suggests that wind-induced transport fluctuations through the Greater Antilles Passages may have played a more significant role in ring separations in that decade and may have occurred with greater frequency during that decade than in prior decades.

Was there a major change in the transport through the Yucatan Channel that contributed to the evolution of the Loop Current in these cases? What role did the wind stress in the GOM play in the evolution of the Loop Current? Was the increased frequency of Loop Current eddy shedding at substantially shorter periods a result of an increased frequency of wind-induced transport fluctuations through the Greater Antilles Passages? These are questions that have no answers presently, but answers to these questions are needed. Many more years of observation will be required to determine if the changes in the Loop Current's eddy shedding observed in the last decade are a low-frequency variation or are permanent changes. Continuous monitoring the Loop Current's eddy shedding is straightforward as long as data are available from satellite altimeters, infrared radiometers, and/or ocean color sensors. However, the MODIS ocean color/IR program is coming to the end. Much of the continuous monitoring of the GOM and the global ocean from satellites will fall on the shoulders of the NPOESS program, a joint NOAA, NASA, and DOD program. It is not clear that NPOESS will provide all the satellite data needed to monitor the GOM and the global oceans properly at this time. Continuous monitoring of wind-induced transport fluctuations through the Greater Antilles Passages, Caribbean eddies, the effects of wind stress in the GOM, or some other feature yet to be determined that may be influencing the Loop Current behavior and eddy shedding, on the other hand, is not straightforward. It requires a monitoring system that does not exist. Global ocean numerical models can provide insight, and modeling of the period 2001-2010 in the GOM should be accomplished, but in the end, hard data are required for validation.

\section{Acknowledgments}

The author would like to thank Frank Monaldo of the Applied Physics Laboratory, Bob Leben of the University of Colorado, and the Ocean Color team at NASA/GSFC, which includes the SAIC support staff, for providing their processed satellite data on the web. Without those data, this study would not have been possible. The author would also like to thank the Minerals Management Service for providing large amounts of processed ship-of-opportunity data and processed data from their numerous field programs in the GOM. Lastly, he would like to thank the various oil and gas companies who provided information from their studies in the GOM.

\section{References}

[1] W. Sturges and J. C. Evans, "On the variability of the Loop Current in the Gulf of Mexico," Journal of Marine Research, vol. 41, no. 4, pp. 639-653, 1983. 
[2] F. M. Vukovich, "Loop Current boundary variations," Journal of Geophysical Research, vol. 93, no. 12, pp. 15585-15591, 1988.

[3] G. A. Maul and F. M. Vukovich, "The relationship between variations in the Gulf of Mexico Loop Current and Straits of Florida volume transport," Journal of Physical Oceanography, vol. 23, no. 5, pp. 785-796, 1993.

[4] F. M. Vukovich, "An updated evaluation of the Loop Current's eddy-shedding frequency," Journal of Geophysical Research, vol. 100, no. C5, pp. 8655-8659, 1995.

[5] W. Sturges and R. Leben, "Frequency of ring separations from the Loop Current in the Gulf of Mexico: a revised estimate," Journal of Physical Oceanography, vol. 30, no. 7, pp. 1814-1819, 2000.

[6] F. M. Vukovich, "Climatology of ocean features in the Gulf of Mexico using satellite remote sensing data," Journal of Physical Oceanography, vol. 37, no. 3, pp. 689-707, 2007.

[7] W. Sturges, "The spectrum of Loop Current variability from gappy data," Journal of Physical Oceanography, vol. 22, no. 11, pp. 1245-1256, 1992.

[8] W. Sturges, "The frequency of ring separations from the Loop Current," Journal of Physical Oceanography, vol. 24, no. 7, pp. 1647-1651, 1994.

[9] D. W. Behringger, R. L. Molinari, and J. F. Festa, "The variability of anticyclonic patterns in the Gulf of Mexico," Journal of Geophysical Research, vol. 82, no. 34, pp. 5469-5478, 1977.

[10] L.-Y. Oey, H.-C. Lee, and W. J. Schmitz Jr., "Effects of winds and Caribbean eddies on the frequency of Loop Current eddy shedding: a numerical model study," Journal of Geophysical Research, vol. 108, no. 10, article 3324, 25 pages, 2003.

[11] J. A. Carton and Y. Chao, "Caribbean Sea eddies inferred from TOPEX/POSEIDON altimetry and a $1 / 6^{\circ}$ Atlantic Ocean model simulation," Journal of Geophysical Research, vol. 104, no. 4, pp. 7743-7752, 1999.

[12] S. J. Murphy, H. E. Hurlburt, and J. J. O’Brien, "The connectivity of eddy variability in the Caribbean Sea, the Gulf of Mexico, and the Atlantic Ocean," Journal of Geophysical Research, vol. 104, no. 1, pp. 1431-1453, 1999. 

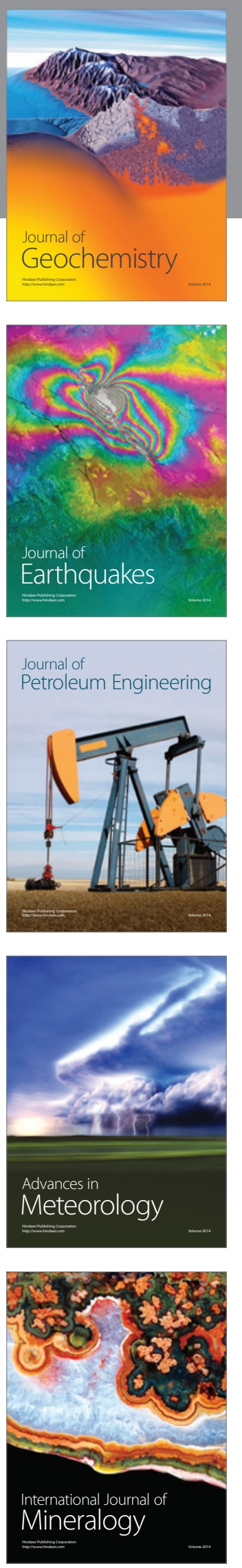
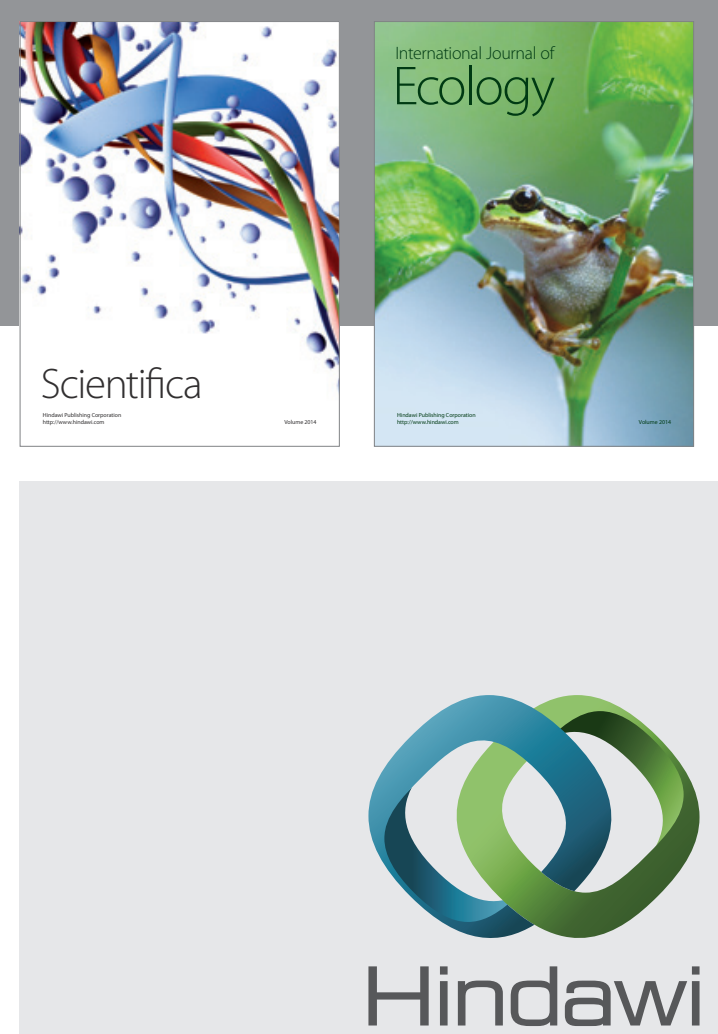

Submit your manuscripts at http://www.hindawi.com
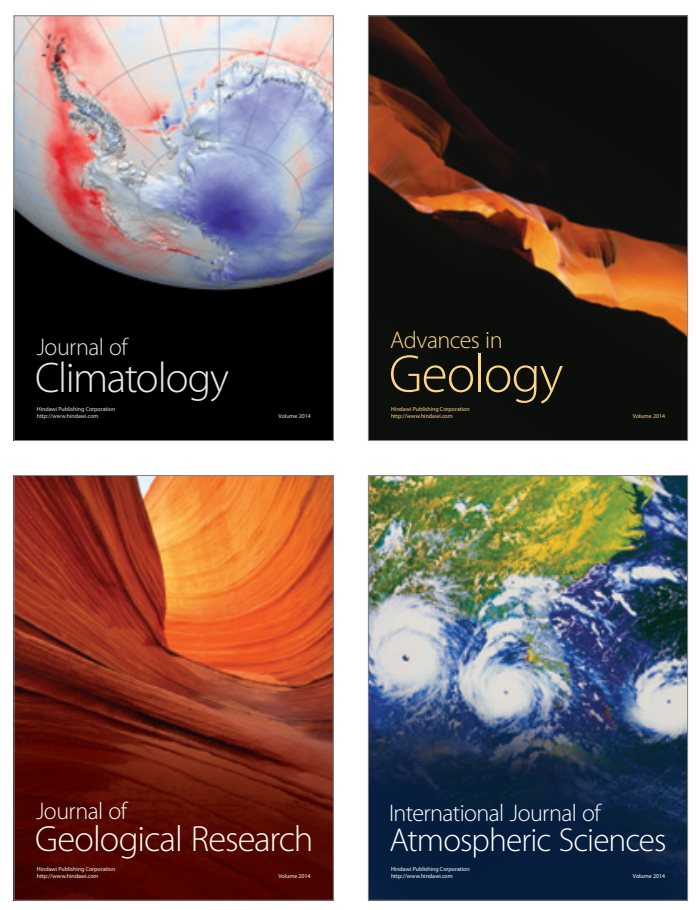
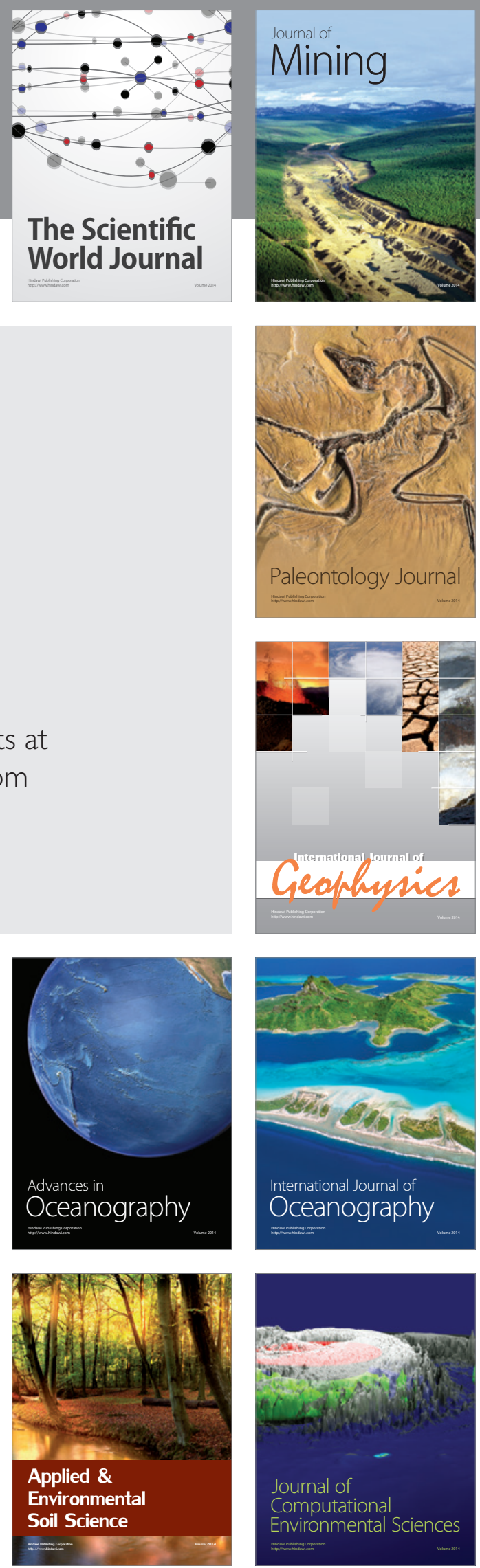